\title{
BRANDING A BUSINESS NAME
}

\author{
Ivan Bulatović ${ }^{1}$, Sanja Škorić², Vladimir Jovanovic ${ }^{3}$
}

\begin{abstract}
Summary
The process of globalization, international businesses, as well as competitive markets imposed the companies (large ones, as well as the others) to position in the required market. Making profit, which is the basic aim of every company, in such market environment can only be achieved by demonstrating distinct characteristics of a company, the characteristics which distinguish it from others with the same or similar activities. Historical and analysis of the current market have shown that being recognizable in the multitude of similar companies is a huge challenge, but also one of the main preconditions for successful operations. The moment a company is registered it acquires a specific identity primarily owing to its business name, which distinguishes it from other companies during that first period. Practically at the same time, the company starts creating its image or goodwill by means of several distinctive ways. One of them is branding business name or corporate branding. However, apart from large benefits, companies may also have big difficulties and risks in the same process as well.
\end{abstract}

Key words: business name, brand, corporate brand

JEL: Q13, M31, K20

\section{Introduction}

Nowadays, companies around the world (with minor exceptions) are recognized as legal entities, which means that a companies are authorized to make autonomous decisions regarding business activities. As a rule, they are registered and may independently operate in the market in their name and on their behalf. In the majority of legal systems, the moment in which company becomes independent and starts its own life apart from its owners as natural persons is the moment of its registration in accordance with the law. However, it was not always the same and even nowadays there are legal theories which completely deny the possibility for companies to be treated as legal subjects. Even though these theories are out of date because

1 Ivan Bulatovic Ph.D, Assistant Professor, Belgrade Business School - College of Professional Studies in Belgrade, Kraljice Marije Street no. 73, Belgrade, Serbia, Phone: +381 113042 300, E-mail: carica@ptt.rs

2 Sanja Škorić Ph.D, Assistant Professor, Law faculty for commercial and judicary in Novi Sad, Geri Karolja Street no. 1, Novi Sad, Serbia, Phone: +381 21400 499, E-mail: sanja@pravni-fakultet.info

3 Vladimir Jovanovic Ph.D, Associate Professor, Faculty of Economics and engineering Management in Novi Sad, Cvecarska Street no. 2, Novi Sad, Phone: +381 21400 484, E-mail: jovanovicvld@gmail.com

EP 2016 (63) 4 (1323-1332) 
of the needs and requirements of contemporary business operations in the world, arguments may still be found that the independence of companies is merely a political decision set by law (Jovanović, 1990). The world trend is to observe companies as completely independent from the founder as legal entities with their own interests which may differ from the interests of owners as well as opposed to them (Guinnane, 2007). If a company is observed this way, then it represents an independent legal entity separated from its owners, founded in order to perform business activities and to make profit. In order to accomplish its basic purpose and aim, the main interest of each company is to be different from other companies in commercial transactions on the basis of personal characteristics, but also to be recognized by consumers and clients. Without that their existence would have been impossible, so special characteristics of company are a precondition for its founding, as well as its subsequent entering into commercial transactions. All this companies achieve owing to their business names when they start their operations, i.e. the name they will use while operating in the market. Even though a conclusion may easily be drawn that being different and stressing unique characteristics is only and exclusively in the interest of the company which wishes to stand out and attract potential clients - that is not true. Namely, differentiating companies is important for several reasons as it provides protection of frequently opposite interest. First of all, the interests of the company itself are protected, and it is really important for the company to build its business image (goodwill) via its business name which will make it recognizable for business associates, clients and consumers (Guinnane, 2007). Also, the interests of consumers and clients are protected this way. They will recognize a company in a multitude of companies with same or similar activities and be able to choose the one which fits them best and stands out. The interests of commercial transactions are also protected, or rather their security due to differentiation of companies which participate in commercial transactions.

Taking all this into consideration, company's business name and its choice appear to be the first necessary step towards achieving company's goals. This is why companies very often pay great attention to the choice of their business names, as well as subsequent changes of it.

\section{Business name of a company}

As we have mentioned in the introduction, a company's business name is the name it uses in legal transactions. The fact that all the companies nowadays are recognized as subjects in commercial transactions and legal entities implies obligation of such a legal entity to have a name which differs from the names of its founders. Company builds its business image on its business name and that very name makes it recognizable in the market. Business law in the legal system of Serbia is relatively new, it was introduced by the Company law in 2004. Before that we had used the word firm to denote business name, which comes from the Latin word firmare, meaning to establish. This term is sometimes considered to be misused since the term firm is used also to talk about the legal entity which employs people. However, the term firm does not denote the name of the company, but the company itself. Although huge significance of the business name as the name a company uses in the market may not be perceived at first, entering into deeper analysis reveals a large number of parameters which put this feature of a company among the top elements of its personalization - sometimes the 
success of business operations itself depends on it, as well as attracting consumers, business partners etc.

The Anglo-Saxon legal system regulates the institute of business name similarly, but it goes a step further when determining its significance and explaining the importance of proper business name choice to all those who intend to start business and register a company. There is a phrase catchy business name, and also some companies which offer their services in choosing the appropriate business name. The choice of business name is of particular importance for those who start a new company, and the main aim of choosing this catchy business name is make the company recognizable in the market in a short time. Apart from that, if we observe the importance of choosing a business name from this perspective, we have to notice its other dimension - the psychological effect on consumers and their perception of the business entity - whether it can be easily remembered, if it is likeable and, as we have already mentioned, ,catchy“. Subsequent business reputation is built upon that psychological and emotional aspect of the business name, and sometimes also corporate brand as well.

\section{Brand and branding}

Product mark, trademark or brand is in use for a really long time. Its primary role was to make particular products distinguishable and different from the others, to assure it is recognizable and easily identified. We may say that brand exists ever since the market itself does. It is believed that it appeared first during classical antiquity in the Mediterranean, primarily in Greece and Rome, as well as Etruscan civilization (Clifton, 2009). The first brands were used for marking products (pottery), for which we have evidence. The primary aim was to protect buyers from bad purchases. Nowadays it has a series of functions, and marks (brands) have evolved from marking some products into a necessary part of everyday life of people which influences their lives in different ways. As for the word itself, the popular word brand comes from an old Scandinavian word brandr, which means burning. The connection with burning becomes clear when we remember that livestock used to be marked by a hot brand so as to identify the owner (Veljković, 2009).

It would have been wrong to assert that branding as marketing category exists for so long in human society. The reason is that the word brand denotes much more than marking products in material or physical manner. The lack of emotion component, communication context and associations with the branded product undoubtedly suggest that beginnings of branding can historically be put in the period after World War II. Consumers' needs suddenly rose first in the United States and a drastic change of market conditions occurred. Because of the higher purchasing power of citizens, purchases were no longer observed solely as the necessity, but for the first time as a pleasure, too, and soon after as a trend. Indistinguishable mass products were failing to satisfy the needs of the new generation of consumers. It became necessary to underline the difference between competitors who offered products, and this required neglecting identical or similar characteristics of the product and creating image instead. 
There are many different definitions of brand. Among the most widely accepted in the literature is the one by the American Marketing Association (AMA): „Mark (brand) is a name, term, design, symbol or any other feature that identifies one seller's good or service as distinct from those of other sellers.“ (Keller, 2003).

Development of mass media - newspaper, radio and television, enabled placing the information before a large audience. Companies recognized this opportunity as the primary channel for promotion of products, i.e. as the channel for creating a demand. Simultaneously, advertising as a new discipline gaining importance rose. It was focused on attracting attention of the targeted audience. The total budget for advertising in the United States in 1950 was 5.7 billion dollars, which was doubled compared to 1945 (2.8 billion) (http://adage.com/). One of the turning points in marketing communications, especially in advertising, was appearance of Leo Burnett agency of Chicago, which started making illustrated characters - mascots in order to introduce a product to consumers in an attractive manner. Emotions which those mascots presented and caused in the audience are the basis of today's branding. Since then emotions, psychology and anthropology were used to feature the value of some product. Since that period companies stopped selling products and started selling brands. An example of that is definitely acquisition of the Kraft company in 1989 by Philip Morris for unimaginable 12.9 billion dollars at the time, which was five times the value of company's assets. Such discrepancy occurred due to the market position of the brands Kraft had had in its portfolio, i.e. positioning relative to buyers, suppliers, distributors, employees etc. (http://books.google. rs/). A quote of former CEO of Coca-Cola Roberto Goizueta speaking of this became very famous: „All our factories and facilities could burn down tomorrow but you'd hardly touch the value of the company; all that actually lies in the goodwill of our brand franchise and the collective knowledge in the company."(Filipović, 2008). This quote underlines the significance of non-material aspects of the brand value.

Marketing, market research and branding are the key factors when it comes to aspirations of companies to establish a quality relationship with users/consumers. If it is based on the quality data regarding consumers, branding may help to increase sale and make consumers loyal. It is believed that the most important role of marketing is creating a brand (Marinković, 2015).

The process of brand creation is complex, long lasting and it demands a clear brand strategy, which should primarily be based on retaining consumers instead of attracting them. Creation of successful brand is based on communication, which may be both external and internal. In the process of branding, a company, its consumers and associates (employees, distributors, agencies, representatives etc.) communicate between, and the company has to find the appropriate way to promote its product or service to all the targeted groups, while at the same time it should be maintaining the necessary consistency in internal and external communication. Cotler and Fitch call marketing connections between the company, associates and consumers the triangle of branding (Marinković, 2015). 


\section{Creating business image by business name branding}

A company becomes independent and acts on its behalf in the market upon registration with the business registry and that is when it acquires the identity. From the moment it starts operations, until the moment of its termination, the company creates its business reputation in the market and in commercial transactions, i.e. its image. If we compare the term identity with the term image, we could say that a company's identity is what it really is, while its image is what others perceive it to be. A perfect situation is when business identity and business image differ only as much as it takes to operate successfully, i.e. when business image is slightly better than the company's identity. However, unlike identity, image is a category created through a longer period, and as a rule it is much harder to gain a good name and reputation than a bad one, which is much harder to fix later (Škorić, 2016). There is a widespread opinion that good reputation needs to be built for years, while it may be lost within a second (http://www.profitmagazin.com/). Business image of a company should be proportionate to its operations, i.e. making profit, which is the basic aim of the company. In other words, this means the business image will be better if the company's total profit is higher and vice versa - the worse the image is, the operations are worse and the profit is lower if the company's reputation is bad. However, this would have been a trivialization of a very important category such as business image, and the business image is all but a simple calculation in the current business environment. Business image is influenced by many factors. Company may influence some of them by its operations, while there are factors totally beyond its control, such as economic and financial changes worldwide, social circumstances, political situation etc. The connection between reputation and success of a company on the one hand and reputation and business name on the other arises from the fact that business image is primarily connected to the business name. If we consider corporate brand as a way to improve business apart from the goodwill, it is completely clear that both terms are connected to the business name of the company.

The value of the business name and brand can be expressed through analyzing financial performance. In economic theory, there are financial analysis, which speak not only about the different aspects of financial position (position and financial structure of the company) on its activities in the financial area (Asset Liability Committee) and on its functioning in the financial field, but also analysis, which through financial statements and attitude sublimated talk about the overall activities of the company, its position and development (Vučićević, 2012). The three most important areas predominantly determine the origin and development of financial analysis, including: financial management, management accounting and financial accounting (Anđelić, 2008) Financial analysis is a function required for the achievement of the objectives and tasks of the financial policy of the company. In modern terms, financials of the company centered on the adoption of the most important financial decisions on investments for the purpose of expansion, growth and development and business analysis of the company; then the financing or acquisition of assets and sources of funding of dividends to shareholders or a profit increase if it is co-owner of the shares in another organizational form of the company 
Brands may be classified according to various criteria. One of them is categorization according to the value. Long/term investments into brand result in the increased value of the company. In accounting terminology, that value is called goodwill and it is more and more frequent in the balances. According to the Forbes list, the most valuable brands nowadays are:

Table 1. The most valuable world brands according to Forbes

\begin{tabular}{|c|c|c|c|}
\hline \multicolumn{5}{|c|}{} & Brand value* & Field \\
\hline Rang & Brand name & 154.1 & Technology \\
\hline 2. & Apple & 82.5 & Technology \\
\hline 3. & Moogle & 75.2 & Technology \\
\hline 4. & Coca-Cola & 58.5 & Beverages \\
\hline 5. & Facebook & 52.6 & Technology \\
\hline 6. & Toyota & 42.1 & Automobile \\
\hline 7. & IBM & 41.4 & Technology \\
\hline 8. & Disney & 39.5 & Amusement \\
\hline 9. & McDonald's & 39.1 & Restaurants \\
\hline 10. & GE & 36.1 & Miscellaneous \\
\hline
\end{tabular}

* Billions of US dollars (\$)

Source: http://www.forbes.com/powerful-brands/list/, 24.9.2016.

\section{The influence of corporate brand on the success of business}

Creation of corporate brand starts even before registration of the company. The first function, definition of corporation, relates to identification of the brand. This includes activities with the aim to define corporate personality, ownership planning, mission, philosophy and definition of basic values, development of the idea, planning of structure and characteristics of the 
company and choosing the name. Successful process of brand development is based on the mutual basic values of the company which facilitate perception of comparable brand and coherent activities in the whole organization. Although basic values as seen as relatively static, they are not since they change during time especially in the dynamic environments with developed technologies (http://zika.rs/).

There are some constants which show the way brand influences creation of value for consumers in case of product brand, product line or corporate brand. Three dimensions are perceived to be crucial:

1. Brand recognizability as its significant dimension increases the value created for consumers. In one of the most important contemporary books on brand management branding is seen as concentrating marketing efforts in order to create image, logo trademark which will distinguish the product in consumer's mind from the competitors' products while at the same time communicating its benefits for consumers (Keller, 2008).

2. Provoking emotions is the second dimension of the brand's influence on consumers - emotional dimension. Famous brands rose above rational observation. Namely, emotions play big role apart from the listed advantages coming form the quality and generally physical and rational characteristics. According to many authors, the emotional component is key for distinguishing successful from the unsuccessful brands. There are many examples of blind tests which demonstrated that some brand is behind the competitive one (e.g. according to the taste), while consumers prefer it when it is packed and branded. This confirms the idea that the brand is far more than rational judgement and that people frequently choose to buy one brand based on who they are when there is a slight difference in other qualities (Vranešević, 2007).

3. Some researches show that branding which is focused on consumer's emotions will be the most efficient one. Combination of colors in the logo and trademark aims to influence the consumer emotionally. The example is Coca-Cola brand which influences the consumers with its bright red color, while emotions of letter design and font associate to liveliness, refreshment and pleasure (Keller, 2008).

4. The third dimension is derived from the previous two, and it is transformation of experience (happening) with the product brand. Convictions regarding certain brand may induce different vision of the characteristics of the product when it is used. Transformation of the experience of using some brand is the reflection of personal opinion of the brand and specific feelings towards it.

Apart from all this, one should not ignore the fact that consumers are the ones allocating the brand its value not just for emotional and irrational reasons. On the contrary, consumers are very rational when they value some brand primarily through quality guarantee which is expected from the brand. Regardless of all the activities aimed at creation and managing of a brand, consumers have the last say. The moment their trust is betrayed by a brand, the company may suffer tremendous losses. 
Large companies have to decide whether they will use corporate brand or individual product brand when they launch new brands. Although they have the same properties and characteristics of the brand, the difference between them could be large if business operations are taken into account.

Corporate branding is different from product branding in several aspects. The first and the most obvious is shifting branding efforts focus from the product to the company (Gligorijević, 2011). Certainly, the product and the company are connected to the corporate brand in the additional economic value of various products and services offered by the company.

However, wider corporate brand tends to rise brand considerations considerably above the product and its relationship with the buyers. Another contrast between the product and business branding is the difference in the person associating the brand with the term, attraction or support. While product brand is mainly focused on consumers and clients, corporate brand also relates to the reputation and tends to keep it same in the eyes of the organization, community, investors, partners, suppliers and other partners (all the stakeholders). Corporate brand relates to all the stakeholders, products and services they exchange through corporation instead to the consumers of various individual products and services.

Authors disagree when it comes to the question whether it is good for a company to create solely corporate brand or a series of product brands (Andžić et al., 2016). As we have already mentioned, a company may aim at creating a corporate brand, i.e. a strong, recognizable company name, such as Nokia, Apple and Virgin. Any product or service of these companies is recognizable and tightly connected to the company. This decreases advertising costs and the costs of attracting consumers. However, the question is what if the reputation of the company or its goodwill is damaged? As a rule, in such cases all the products of one company are endangered if its reputation is damaged.

When a company creates a series of different brands and does not associate them with the business name, in case of loss of reputation, the brands do not have to suffer. However, this type of branding as a rule is far more expensive since each new brand requires a lot of money in order to be positioned in the mind of consumers. Unlike product brand, corporate brand may always count on previously acquired reputation.

Finally, the conclusion is that company owners or managers should decide for business name branding - corporate branding, or single product or product line branding. Either way the decision has to be made based on market environment and preferences of producers and business partners. Own brand is a big success for a company since it provides revenue and lasts for a long period of time.

\section{Literature}

1. Anđelić, D., Jovićević, P. (2008): Analiza finansijskih izveštaja i poslovanja preduzeća; Zbornik radova Fakulteta za ekonomiju i inženjerski menaxment u Novom Sadu, no. 1, p. 184, Fakultet za inženjerski menadžment u Novom Sadu, Novi Sad, Srbija. 
2. Andžić, S., Rajković, M., Ćosić, M. (2016): Nefinansijski aspekti poslovanja kao faktori razvoja preduzetništva, Oditor, Belgrade, Serbia, vol. 2, no. 2, pp. 7-17.

3. Carić, S. (2000): Pravni položaj privrednih organizacija; Centar za privredni konsalting, Novi Sad, Srbija.

4. Clifton, R. (2009): Brands and Branding; The Economist, London, pp. 11, England.

5. Filipović, V. (2008): Brend menadžment, Fakultet organizacionih nauka, Beograd, Srbija.

6. Gligorijević, M. (2011): Specifičnosti izgradnje Brenda na poslovnom tržištu; Marketing vol. 42, no. 3, pp. 141-149. Beograd, Srbija.

7. Guinnane, T., Harris, R., Lamoreaux, R., Naomi Rosenthal, Jean-Laurent. (2007): Putting the Corporation in its Place; Oxford University Press on behalf of the Business History Conference. Advance Access publication July 19, pp. 678-729, England.

8. Jovanović, V. (1990): Preduzeća i društva prema Zakonu o preduzećima; Beograd, Srbija.

9. Keller, K.L., Aperia T., Georgson M. (2007): Strategic Brand Management - A European perspective; Pearson Education Limited, Harlow, England.

10. Keller, K.L. (2003): Building, Measuring and Managing Brand Equity; second edition, Pearson Education, New Jersey, USA.

11. Marinković, V. (2015): Upravljanje vrednošću brenda sa posebnim osvrtom na emocionalni aspekt brendiranja; Ekonomski signali: poslovni magazin, vol. 10, no. 2, pp. 71-83., Beograd, Srbija.

12. Škorić, S (2016): Uticaj poslovnog imena privrednog društva na njegovo poslovanje; Doktorska disertacija, Pravni fakultet za privredu i pravosuđe u Novom Sadu, Novi Sad, Srbija

13. Tepavac, D., Kostić Stanković, M. (2014): Značaj korporativne društvene odgovornosti na kreiranje brenda; Marketing vol. 45, no. 1, pp. 29-40, Beograd, Srbija.

14. Veljković, S., Đorđević, A. (2009): Vrednost brenda za potrošače i preduzeća; Marketing no. 1, pp. 3-16., Beograd, Srbija.

15. Vranešević T. (2007): Upravljanje markama (Brand Management); Accent, Zagreb, Hrvatska.

16. Vučević, D. (2012): Teorijski aspekti i osnovne postavke finansijske analize; Škola biznisa, no. 2, p. 82., Beograd, Srbija.

17. http://adage.com/article/75-years-of-ideas/1940s-war-cold-warconsumerism/102702/, accessed on 19.9.2016.

18. https://books.google.rs/books? id=mWSmBgAAQBAJ\&pg=PA426, accessed on 20.9.2016.

19. http://www.profitmagazin.com/izdanje/broj_6.57.html - accessed on 20.09.2016. 
20. http://www.forbes.com/powerful-brands/list/ accessed on 24.9.2016.

21. http://www.zika.rs/index.php?option=com_content\&view=article\&id=1241:korpor - accessed on 24.09.2016.

\title{
BRENDIRANJA POSLOVNOG IMENA KOMPANIJA
}

\author{
Ivan Bulatovičc ${ }^{4}$ Sanja ŠKoric ${ }^{5}$ Vladimir Jovanovićc ${ }^{6}$
}

\begin{abstract}
Apstrakt
Proces globalizacije $i$ internacionalizacije poslovanja, kao i velika konkurencija na tržištu, nametnuli su potrebu svim kompanijama (kako tzv. velikim, tako i onim drugim) potrebu pozicioniranja na datom tržištu. Sticanje profita, kao osnovni cilj svake kompanije, $u$ današnjim uslovima poslovanja, moguće je ostvariti samo izdvajanjem kompanije po odgovarajućim karakteristikama od mnoštva drugih koje se bave istom ili sličnom delatnošću. Istorijskom analizom, ali i analizom postojećeg stanja na tržištu, utvrđeno je da biti prepoznat u mnoštvu sličnih je postao ogroman izazov, ali i jedan od glavnih uslova za uspešno poslovanje kompanija. Umomentu osnivanja, kompanija stiče svoj poseban identitet koji gradi prvenstveno preko poslovnog imena, koji je i u tom inicijalnom periodu odvaja od drugih kompanija. Gotovo istovremeno, kompanija počinje sa izradnjom svog imidža ili goodwill-a, i pritom ima na raspolaganju više različitih načina na koji to čini. Jedan od njih jeste pristupanje brendiranju svog poslovnog imena ili korporativno brendiranje. Međutim, osim velikih benefita, kompanije mogu u navedenom procesu imati i velike poteškoće i rizike.
\end{abstract}

Ključne reči: poslovno ime, brend, korporativni brend

4 Profesor strukovnih studija, dr Ivan Bulatović, Beogradska poslovna škola - Visoka škola strukovnih studija u Beogradu, Ulica Kraljice Marije br. 73, Beograd, Telefon: +381 113042 300, E-mail: carica@ptt.rs

5 Docent, dr Sanja Škorić, Pravni fakultet za privredu i pravosuđe u Novom Sadu, Ulica Geri Karolja br. 1, Telefon: +381 21400 499, E-mail: sanja@pravni-fakultet.info

6 Vanredni profesor, dr Vladimir Jovanović, Fakultet za ekonomiju i inženjerski menadžment u Novom Sadu, Ulica Cvećarska br. 2, Telefon: +381 21400 484, E-mail: jovanovicvld@gmail.com 